\title{
Are Cities Safer Than Before?
}

\author{
Guangwei Huang * \\ Graduate School of Global Environmental Studies, Sophia University, Tokyo, Japan
}

Cities are built to lead better lives. However, irrational urban development has led in reverse, causing numerous problems. The increase in flood risk in urbanized areas is one of the significant problems. Despite extensive research, numerous engineering projects have been carried out to reduce the risk of flooding, the question "are we safer than before?" remains underexplored. The present work is a case study aimed at providing new evidence of the current state of flood disaster management. It analyzed the relationship between the magnitude of flood and resultant flood fatality and property damage in the target area over a long period of time and found that we are safer now than before in terms of life loss, but not safer than before in terms of flooding impacts on livelihood. Most importantly, it was found that flood risk management in the region continues to be critically dependent on structural measures. Besides, it highlighted a contrast between having a well-developed emergency information delivery system and its ineffectiveness in mobilizing evacuation.

Keywords: flood fatality, property damage, Chikuma River, vulnerability, levee breach

\section{OPEN ACCESS}

Edited by:

Yang Zhou,

Shenzhen University, China

Reviewed by:

Jinxin Zhu,

Sun Yat-sen University, China Jiapei Chen,

University of Regina, Canada

*Correspondence:

Guangwei Huang

huanggwx@sophia.ac.jp

Specialty section:

This article was submitted to Urban Resource Management, a section of the journal

Frontiers in Sustainable Cities

Received: 22 May 2021

Accepted: 25 June 2021

Published: 23 July 2021

Citation:

Huang G (2021) Are Cities Safer Than

Before?

Front. Sustain. Cities 3:713300. doi: 10.3389/frsc.2021.713300

\section{INTRODUCTION}

Human beings have been suffering from many natural disasters, including earthquakes, landslides and flooding. The fighting against flood disasters can be traced back to at least 2000 years ago when the Dujiangyan Irrigation System was created for flood control, irrigation water supply, and river channel siltation prevention (Cao et al., 2010). Since ancient times, many methods and techniques have been developed for flood control, including the constructions of floodwater diversion channels, levees, dams, reservoirs, and retention ponds to hold extra water during floods (Komatsu et al., 2008; Kundzewicza et al., 2018; Ogie et al., 2020). In addition to these structural measures, non-structural measures such as flood hazard mapping, early warning systems, and land use planning have been studied extensively in recent decades (Kundzewicz, 2002; Schanze et al., 2008; Dawson et al., 2011; Jamrussri and Toda, 2017; Raffaele De et al., 2020). Despite various efforts and progress, flooding has become the most common natural hazard facing cities globally (CRED, 2012). A fundamental cause for this consequence is the rapid and often poorly planned urbanization. Given that irrational urban developments have caused, research initiatives such as low impact development, green infrastructure and sponge city have been proposed and promoted in various ways. In the early 1990s, Prince George's County, Maryland, introduced the concept of lowimpact development (LID) as an alternative to traditional storm water management best practices (Roy et al., 2000). It uses rain garden, green roofs, retention ponds and porous pavements and other measures to attenuate and prevent runoff peaks and thereby reduce flood impacts (Jackisch and Weiler, 2017). Other LID strategies include the preservation or protection of ecologically sensitive site features such as riparian buffers, wetlands, steep slopes, valuable trees, floodplains, woodlands and highly permeable soils. LID practices offer an additional advantage in that they can be integrated into infrastructure and are more cost-effective and aesthetically appealing than traditional structural stormwater systems (Akagwu et al., 2017). 
Pioneered in Australia, water-sensitive urban design (WSUD) is a land planning and engineering design approach which integrates the urban water cycle, including stormwater, groundwater and wastewater management and water supply, into urban design to create urban environments that allow the water cycle to function as it would naturally (Roy et al., 2008). In the United Kingdom, a similar initiative is named Sustainable urban drainage systems (SuDS) (The British Geological Survey). Both aim to harmonize modern drainage systems with natural water processes in order to reduce the effects of urban development.

A new urban water management model, known as sponge city, was developed in China (Yu et al., 2015). A sponge city is a new urban construction model for flood management, strengthening ecological infrastructure and drainage systems. It can alleviate the city's waterlogging, water resources shortage, and urban heat island effect and improve the ecological environment and biodiversity by absorbing and capturing rain water and utilize it. Rainwater harvested can be used for irrigation and for home use. It is a form of a sustainable drainage system on an urban scale. The new mode of thinking is to design a city in such a way that it retains all the surface water runoff that occurs within the confines of the city and that it can be reused later, thereby creating an urban environment that absorbs the water then releases that water when required-in a similar manner to a sponge (Chan et al., 2018).

Despite so much research aimed at reducing urban floodrelated disasters, we have witnessed the frequent recurrence of urban flood-related disasters worldwide. According to the International Federation of Red Cross and Red Crescent International Federation of Red (2015), there were $~ 59,092$ flood-related deaths in the world between 2005 and 2014 . Consequently, the reduction of life loss due to natural hazards was identified as a priority outcome in the Sendai Framework for Disaster Risk Reduction 2015-2030 (UNISDR 2015). A study by Diakakis and Deligiannakis (2017) examined floodrelated deaths in Greece between 1970 and 2010 and found no significant upward or downward trends, but a high seasonality was recognized. Huang (2014) showed that flood-related deaths in China and Japan have declined, but economic losses from flooding have remained high. Petrucci et al. (2019) analyzes flood fatality in eight EU countries using a 39-year database and showed a stable trend in flood fatalities, despite individual trends up and down. Paprotny et al. (2018) studied 37 European countries with a new database of damaging floods since 1870 and the results indicate that, after correcting for changes in flood exposure, there has been an increase in annually inundated area and number of persons affected since 1870, contrasted by a substantial decrease in flood fatalities. Singh and Kumar (2013) showed that the numbers of flood events and human fatalities have increased over the period of 1978-2006 in India. These studies provided valuable insights into flood risk management in different parts of the world, but this information is aggregated at different scales from global, regional to national, the determinants of flood fatalities and economic loss have not been sufficiently analyzed and adequately explained. To assess the effectiveness of various countermeasures, more post-Odin case studies at the local level are necessary to better understand

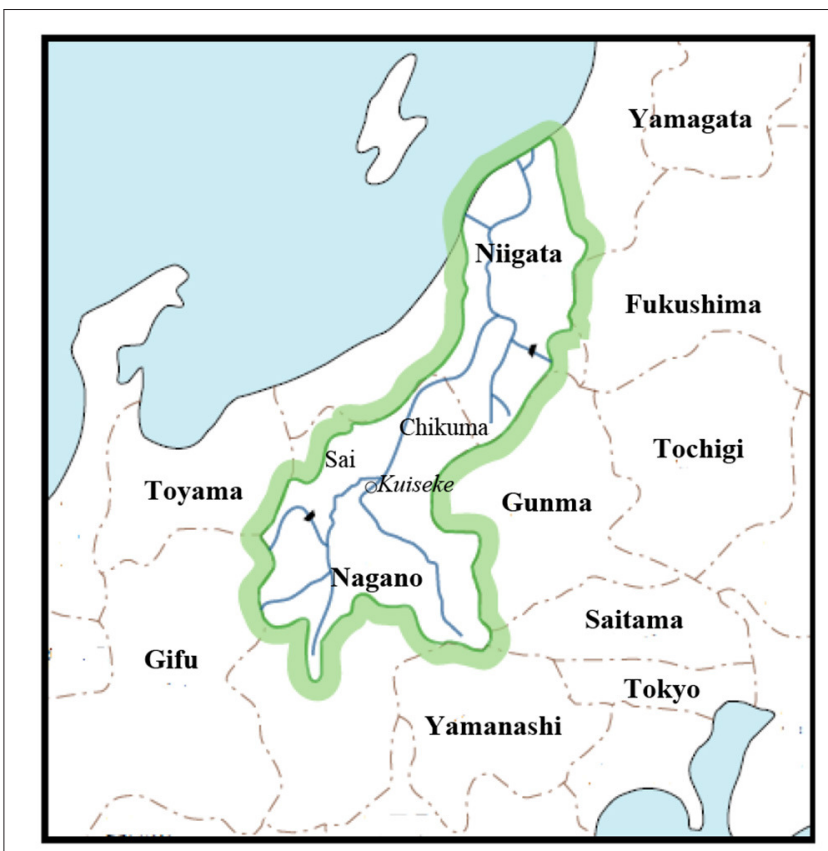

FIGURE 1 | Watershed of the Chikuma-Shinano River.

and propose new measures as a result. Following this line of thinking, the present study focused on a flood-prone area in Nagano Prefecture, Japan, and was intended to provide a diagnosis of how flood impacts in this area have evolved over time. Such a diagnosis offers new insights into our safety in relation to flooding.

\section{STUDY SITE AND METHODS}

This study covers the Chikuma River watershed with a particular focus on the Nagnuma district in Nagano City. Chikuma River is the upper reaches of the Shinano River, the longest river in Japan. As shown in Figure 1, originatedin the Japanese Alps, the Chikuma-Shinano river course runs northeast through Nagano and Niigata Prefectures before emptying into the Sea of Japan. The length of the Chikuma river is $214 \mathrm{~km}$, and its watershed area is $7100 \mathrm{~km}^{2}$, accounting for $60 \%$ of the whole watershed area of the Chikuma-Shinano river course. Nagano City has a population of 370,632 in 160,625 households, while the Naganuma district has a population of 2,497 in 918 families. The total areas of Nagano City and Naganuma district are 834.81 and $6.17 \mathrm{~km}^{2}$, respectively. The aging rate, which is defined as the proportion of a society's population that is comprised of persons aged 65 or above, is as high as $38.2 \%$ in the Naganuma district. Chikuma River runs through the city $29.5 \mathrm{~km}$ within the Nagano city boundary and the Naganuma district is located on the left bank of the Chikuma River.

Historical records showed that 26 large-scale flood disasters have occurred in the watershed of Chikuma River from 1742 to 2020 and 11 of them occurred since 1980. The present study collected information and data related to these 
floods from both central and local governments [MLIT (Ministry of Land, Infrastructure, Transport and Tourism), Chikuma River Information Room]. Data were analyzed with mixed methods, which allows us to explore the complex situation in the watershed from diverse perspectives and uncover relationships between the intricate layers of multifaceted research questions. The mixed methods employed in the present study is to use qualitative approach for the characterization of the local conditions and risk factors, and quantitative approach for in-depth relationship analysis to discover contradiction. In particular, the present study scrutinized the relationship between the magnitude of external force and flood fatality and property damage. Then, the attention was placed on the latest flood disaster that occurred in 2019. A focal point is the vulnerability of the elderly and foreign residents. By presenting a contrast between having a well-developed emergency information delivery system and its effectiveness in mobilizing residents to take action, it highlights what should be done next. Besides, by elucidating a key factor forming the flood risk in the area, it stresses the need for more proactive management.

\section{RESULTS AND DISCUSSIONS}

\section{Results}

Among 26 major flood disasters in the watershed of Chikuma River from 1742 to 2020 , flood fatality data are available for 18 of them, as compiled in Supplementary Table 1. The flood disaster in 1742 was exceptional. Continuous rainfall from July 27 to Aug. 1 due to a strong Typhoon caused a levee breach and flood waters coming out of the Chikuma River left the historically highest flood marker in a nearby temple. The death toll was as high as 2800 . Since the nineteenth century, the flood fatality in the watershed of the Chikuma River never exceeded 100 except in 1961. In 1961, although levee breach was avoided, the number of deaths is the second-highest in the history of the Chikuma River. Excluding the number for the year of 1742 as a statistical anomaly, t-test indicated that the difference in average number of death before and after 1981 is statistically significant. Among 9 major flood disasters that occurred after 1980, five of them were caused by typhoons. Among the five, three had levee breach including the latest one in 2019. The embankment collapse once every 10 years in the mainstream of the Chikuma River can be considered a severe management failure in a technologically advanced country. It is worth mentioning that the experience of the Typhoon Isewan in 1959 led to the passage of Soil Conservation and the Flood Control Urgent Measures Act and Flood Control Special Account Act in 1960, and intensive implementation of flood control measures afterwards. By 1984, $60 \%$ of the planned river improvement works for flood control were completed along the major Japanese rivers (Huang, 2014). Besides, flood hazard mapping started in 1993. The combination of structural and non-structural measures can be considered the main reason for the flood fatality reduction since 1985 in Figure 2.

Figure 2 shows the relationship between flow discharge at the Tategahana gauging station and the number of houses inundated

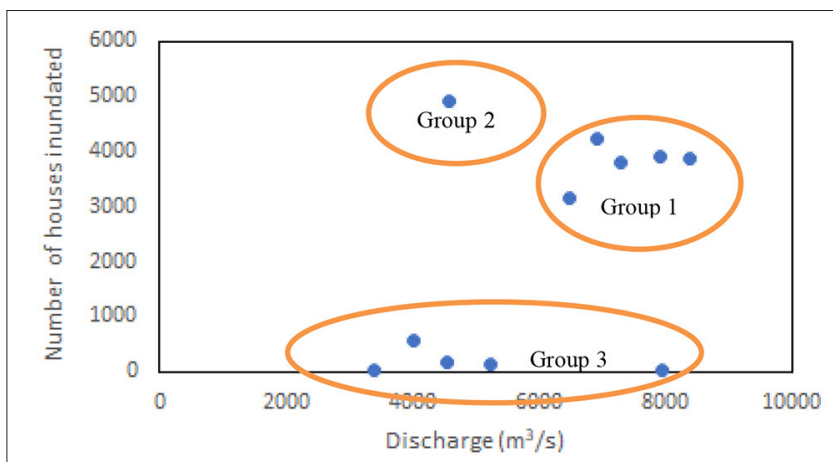

FIGURE 2 | Relationship between flow discharge at the Tategahana gauging station and the number of houses inundated above floor level in the watershed of the Chikuma River for 11 major floods since 1958.

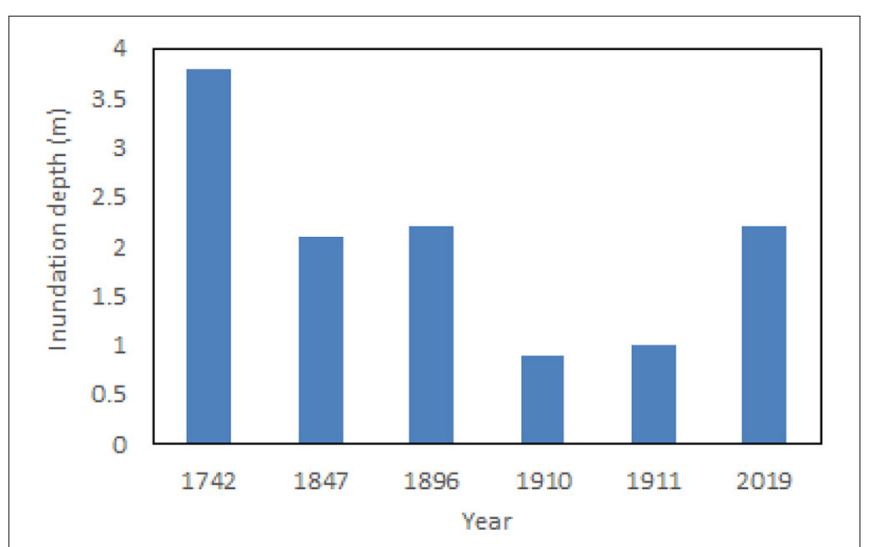

FIGURE 3 | Inundation depths at the same site in different flood disasters.

above floor level for 11 major floods since 1958. By examining causes of flooding, the available data were divided into three groups. Group 1 represents cases that the levee breach occurred along the mainstream of the Chikuma River; Group 2 illustrates a case that the levee breach occurred along tributaries of the Chikuma River; and Group 3 represents cases that flooding was due to overflow and waterlogging, not caused by embankment collapse. As seen clearly from the figure, levee breach is a crucial determinant of the magnitude of property damage. Once levee breach occurred, property damage became quite the same high although time has passed with so many efforts made for damage reduction.

On October 13, 2019, the heavy rainfall due to Typhoon No. 9 caused a levee breach on the left bank of the Chikuma River in the Naganuma district, Nagano City. The Naganuma district has suffered several large flood disasters since the Edo period. Figure 3 shows historical inundation depths marked on the pillar of a temple near the breaching site and the inundation depth at almost the same site in 2019 according to the author's survey.

Figure 4 shows the variation of river channel width along the Chikuma River. A factor affecting the water level at the Naganuma site is the back water effect due to the river width 


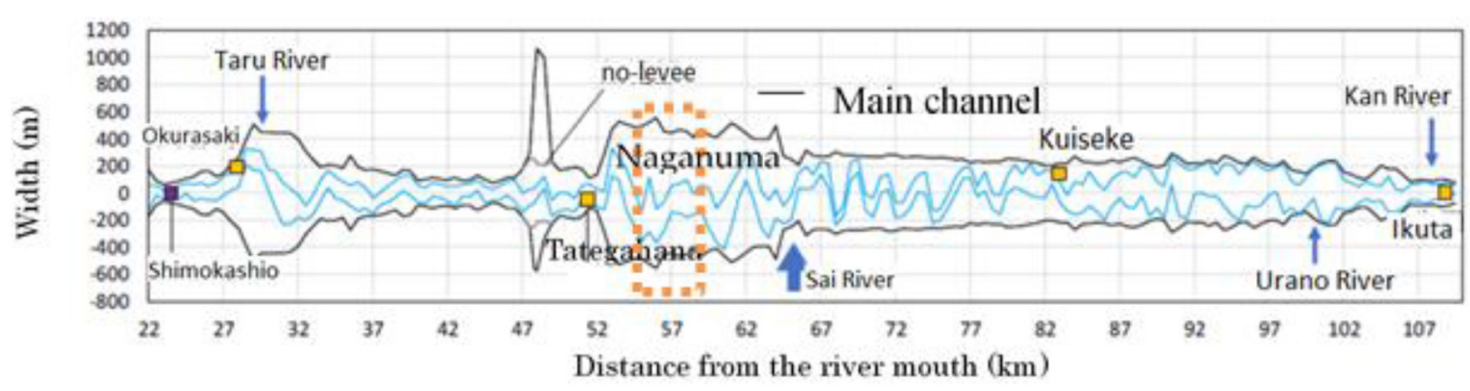

FIGURE 4 | The bottleneck in channel conveyance due to sudden contraction in width. (data source: MLIT).

sudden contraction at the Tategahana cross-section, which is $6 \mathrm{~km}$ downstream of the Naganuma. The bottleneck was formed due to the geology and has been identified as a major concern in the river basin planning for passing large-scale floods. However, engineering countermeasures had not been taken before the disaster for mainly three reasons. One is the cost because it is surrounded by mountains. The second is the consideration of environmental impacts and the third is the consideration of the downstream reaches. If the width expanded, more flood waters could be passed to the downstream, increasing flood risk there. The 2019 flood disaster served as a turning point. In 2020, the Ministry of Land announced a plan to excavate the channel along the narrower river reach to increase its conveyance, which was already started in Feb. 2021 and will be completed in 2015.

As provided in Supplementary Table 2, the flood discharge in 2006 is less than that in 1958 and 1981, however, the water level is higher than in 1958 and 1981. The peak flow in 2019 is $8387 \mathrm{~m}^{3} / \mathrm{s}$, less than the design flood discharge of $9000 \mathrm{~m}^{3} / \mathrm{s}$. However, the water level is $12.11 \mathrm{~m}$, exceeding the high water level $(10.75 \mathrm{~m})$. These data are evidence that the channel aggradation occurred in the narrow reach. Therefore, the government decision of excavation is justified.

This flooding caused five deaths in the watershed of the Chikuma River. Four male and one female and their ages are $81,81,81,68$ and 69 . Two of them died while driving as their cars were washed away. One man lost his life in his house near the levee breaching site although he was urged to evacuate. This case provided additional evidence that Japan's aging society has caused more older people to become victims of flood disasters.

Disaster Response Headquarter was set up at 4:20 p.m. on Saturday, October 12, which consisted of teams such as the evacuation team, humanitarian aid team and victim support team. The meetings of the headquarter for emergency response were conducted online and connected to branch offices in different districts and evacuation shelters so that information sharing was effective without any delay. Using a five-level alert system, Disaster Response Headquarter issued the warning of alert level 3 for evacuation preparation and the start of evacuation for the elderly twice, alert level 4 as evacuation advisory 3 times, alert level 4 as evacuation instruction (emergency) 8 times, and finally, alert level 5 as disaster occurrence information 10 times. Evacuation information was sent out via various means, including radio, emails, and loudspeakers. For resident with hearing difficulties, the evacuation information was sent to them by fax (Nagano City).

\section{DISCUSSIONS}

The Nagano City has a well-designed emergency management system and worked effectively during the flood disaster. Nonetheless, $\sim 200$ seniors were stranded in two special care homes by flood waters and rescued by the Ground Self-Defense Force. The special nursing care homes received the warning and evacuation information timely, but the limited number of staff were unable to move a large number of residents to a safe place. Instead of moving out, the staff moved all seniors to the second floor of the facility and waited for rescue. Factors that increase the potential for injury or death due to disasters include physical vulnerabilities and external influences. The vulnerability of the elderly to disasters is largely due to their weakened physical ability to move, lowered sensory awareness, cognitive decline limiting the understanding of risk communication, evacuation instructions, thus hindering appropriate protective responses. Visual or hearing disabilities are more serious barriers to emergency response, although they are not limited to seniors. Besides, many older adults needing medication in daily life are at risk when medical supplies and equipment to maintain their health become unavailable in a crisis.

Vulnerability can be formulated conceptually as below:

Vulnerabilty $=($ Exposure $\times$ Susceptibility $) /($ CopingCapacity $)(1)$

Where exposure is defined as the degree, duration and extent to which a system is in contact with, or subject to, perturbation. Susceptibility can be defined as factors and attributes that make a community or society more or less likely to be negatively affected by perturbation. Coping capacity is defined as the ability to cope with, or absorb and adapt to, hazard impacts. It is the product of planned preparation before a disaster, emergency response during the disaster and post-disaster reconstruction.

This study has shown that indeed, flood vulnerability reduction depends in large part on structural measures. Once a levee breach occurred, the property damage will remain the same today as before. The reason for this is that many houses are still in flood-prone areas. Should the levee fail, the exposure 
would be the same as the one without the levee or even worse. Furthermore, as society is aging, the susceptibility of local communities to disasters has been increased, but the copping capacity has not been sufficiently increased to counteract the increase in susceptibility.

It can be argued that structural flood protection measures, in addition to their anticipated benefits, have unintended effects that, paradoxically, appear to increase the risk. Structural measures such as levees or flood-control reservoirs can attract settlements and high-value assets in the areas "protected," due to a sense of complacency that may dangerously reduce preparedness.

\section{CONCLUSION}

For the city in question, it is safer today than before in terms of loss of life, but not in terms of the impact of floods on livelihoods. In fact, the effectiveness of flood management in the city still depends heavily on structural measures. Once a structural failure has occurred, impacts would remain significant. Moreover, the problem of the bottleneck in channel conveyance remains intact until now despite its identification. In addition, aging increase

\section{REFERENCES}

Akagwu, M., Fadamiro, J. A., and Ayeni, D. A. (2017). Evaluation of environmental aesthetics of residential plots, through low impact development strategies, in satellite town, Lagos, Nigeria. Int. J. Develop. Res. 7, 12102-12107.

Cao, S., Liu, X., and Huang, E. (2010). Dujiangyan Irrigation System-a world cultural heritage corresponding to concepts of modern hydraulic science. J. Hydro-Environ. Res. 4, 3-13. doi: 10.1016/j.jher.2009. 09.003

Chan, F. K. S., Griffiths, J. A., Higgitte, D., Xu, S., Zhu, F., Tang, Y. T., et al. (2018). "Sponge City" in China-a breakthrough of planning and flood risk management in the urban context. Land Use Policy 76, 772-778. doi: 10.1016/j.landusepol.2018.03.005

Chikuma River Information Room. Chikuma River Office, Hokuriku Regional Development Bureau, Ministry of Land, Infrastructure and Transport. Available online at: http://www.hrr.mlit.go.jp/chikuma/shiru/kouzui/index. html (accessed March 15, 2021).

CRED (2012). Disaster Data: A Balanced Perspective, Report 299. Centre for Research on the Epidemiology of Disasters. Available online at: http://cred.epid. ucl.ac.be/f/CredCrunch29.pdf. (accessed April 1, 2020).

Dawson, R. J., Bob, T., Werritty, J., Werritty, A., Hall, J. W., and Roche, N. (2011). Assessing the effectiveness of non-structural flood management measures in the Thames Estuary under conditions of socio-economic and environmental change. Glob. Environ. Change 21, 628-646. doi: 10.1016/j.gloenvcha.2011.01.013

Diakakis, M., and Deligiannakis, G. (2017). Flood fatalities in Greece: 1970-2010. J. Flood Risk Manage. 10, 115-123. doi: 10.1111/jfr3.12166

Huang, G. W. (2014). Does a kuznets curve apply to flood fatality?a holistic study for China and Japan. Nat. Hazards 71, 2029-2042. doi: 10.1007/s11069-013-0994-2

International Federation of Red, Cross, and Red Crescent, Societies (2015). World Disasters Report 2015.

Jackisch, N., and Weiler, M. (2017). The hydrologic outcome of a Low Impact Development (LID) site including superposition with streamflow peaks. Urban Water J. 14, 143-159. doi: 10.1080/1573062X.2015. 1080735

Jamrussri, S., and Toda, Y. (2017). Simulating past severe food events to evaluate the effectivenessof nonstructural food countermeasures in the upper Chao Phraya River Basin, Thailand. J. Hydrol. Reg. Stud. 10, 82-94. doi: 10.1016/j.ejrh.2017.02.001 local susceptibility. While this is only a case study, the results provide invaluable clues to other cities to improve their flood risk management.

\section{DATA AVAILABILITY STATEMENT}

The original contributions presented in the study are included in the article/Supplementary Material, further inquiries can be directed to the corresponding author/s.

\section{AUTHOR CONTRIBUTIONS}

The author confirms being the sole contributor of this work and has approved it for publication.

\section{SUPPLEMENTARY MATERIAL}

The Supplementary Material for this article can be found online at: https://www.frontiersin.org/articles/10.3389/frsc.2021. 713300/full\#supplementary-material

Komatsu, T., Sugio, S., Hikida, M., Ohmoto, T., Oshikawa, H., and Hashimoto, A (2008). An outline of the flood disasters in the Seadai River in July 2006 and the review of flood control by dam operation. Proc. Hydraul. Eng. 52, 805-810. doi: 10.2208/prohe.52.805

Kundzewicz, Z. W. (2002). Non-structural flood protection and sustainability. Water Int. 27, 3-13. doi: 10.1080/025080602086 86972

Kundzewicza, Z. W., Heggerc, D. L. T., Matczakd, P., and Driessen, P. P. J. (2018) Opinion: flood-risk reduction: structural measures and diverse strategies. Proc. Natl. Acad. Sci. U. S. A. 115, 12321-12325. doi: 10.1073/pnas.18182 27115

MLIT. History of flood disaster and change in flood risk management. Available online at: https://www.mlit.go.jp/river/basic_info/jigyo_keikaku/gaiyou/seibi/ pdf/shinanogawa35-5-4.pdf (accessed March 15, 2021).

Nagano City. Reiwa East Japan Typhoon Disaster Response Validation report.

Ogie, R. I., Adam, C., and Perez, P. (2020). A review of structural approach to flood management in coastal megacities of developing nations: current research and future directions. J. Environ. Plann. Manage. 63, 127-147. doi: 10.1080/09640568.2018.15 47693

Paprotny, D., Antonia, S. E., Oswaldo M. N., Sebastiaan, N. J. (2018). Trends in flood losses in Europe over the past 150 years. Nat. Commun. 9, Article number: doi: 10.1038/s41467-018-04253-1

Petrucci, O., Luigi, O., Aceto, L., Bianchi, C., et al. (2019). Flood fatalities in Europe, 1980-2018: variability, features, and lessons to learn. Water 11:1682. doi: $10.3390 /$ w11081682

Raffaele De, R., Fatemeh, J., Francesco De, P., Stefano, C., Nebyou, Y., Maurizio, G., et al. (2020). From flood risk mapping towards reducing vulnerability: the case of Addis Ababa. Nat. Hazards 100, 387-415. doi: 10.1007/s11069-019-0 3817-8

Roy, A. H., Wenger, S. J., Fletcher, T. D., Walsh, C. J., Ladson, A. R., Shuster, W. D., et al. (2008). Impediments and solutions to sustainable, watershed-scale urban stormwater management: Lessons from Australia and the United States. Environ. Manage. 42, 344-359. doi: 10.1007/s00267-0089119-1

Roy, S. P., Mohammed, L., Leslie, S., Michael, C., Mow-Soung, C., and Derik, W. (2000). Low impact development design strategies, an integrated design approach. USEPA 841-B-00-003.

Schanze, J., Hutter, G., Penning-Rowsell, E., Nachtnebel, H.-P., Meyer, V., Werritty, A., et al. (2008). Systematisation, evaluation and context conditions 
of structural and non-structural measures for flood risk reduction. FLOODERA joint report, published by ERA-NET CRUE, Available online at: http:// www.crue-eranet.net

Singh, O., and Kumar, M. (2013). Flood events, fatalities and damages in India from 1978 to 2006. Nat. Hazards 69:1815-1834. doi: 10.1007/s11069-013-0781-0

The British Geological Survey. Available online at: https://www.bgs.ac.uk/geologyprojects/suds/ (accessed March 15, 2021).

Yu, K. J., Li, D. H., Yuan, H., Fu, W., Qiao, Q., and Wang, S. S. (2015). “Sponge City": Theory and practice. City Plann. Rev. 39, 26-36.

Conflict of Interest: The author declares that the research was conducted in the absence of any commercial or financial relationships that could be construed as a potential conflict of interest.
Publisher's Note: All claims expressed in this article are solely those of the authors and do not necessarily represent those of their affiliated organizations, or those of the publisher, the editors and the reviewers. Any product that may be evaluated in this article, or claim that may be made by its manufacturer, is not guaranteed or endorsed by the publisher.

Copyright (C) 2021 Huang. This is an open-access article distributed under the terms of the Creative Commons Attribution License (CC BY). The use, distribution or reproduction in other forums is permitted, provided the original author(s) and the copyright owner(s) are credited and that the original publication in this journal is cited, in accordance with accepted academic practice. No use, distribution or reproduction is permitted which does not comply with these terms. 